\title{
Regulation of chemokine and chemokine receptor expression by PPARG in adipocytes and macrophages
}

\author{
MT Audrey Nguyen ${ }^{1 \dagger}$, Ai Chen ${ }^{1 \dagger}$, Wendell J Lu ${ }^{1}$, WuQiang Fan ${ }^{1}$, Ping-Ping Li ${ }^{1}$, Dayoung Oh ${ }^{1}$, David Patsouris ${ }^{1,2^{*}}$ \\ From 6th European Workshop on Immune-Mediated Inflammatory Diseases \\ Nice, France. 23-25 November 2011
}

\section{Background}

PPARG plays a key role in adipocyte biology, and Rosiglitazone (Rosi), a thiazolidinedione (TZD)/ PPARG agonist, is a potent insulin-sensitizing agent [1-3]. Recent evidences demonstrate that adipose tissue inflammation links obesity with insulin resistance and that the insulin-sensitizing effects of TZDs result, in part, from their anti-inflammatory properties $[4,5]$. However the underlying mechanisms are unclear. Free Fatty Acids (FFAs) are important adipocyte-derived signaling molecules whose plasma levels are elevated in obese and insulin resistant individuals and animal models [6,7]. In this study, we establish a link between free fatty acids (FFAs) and PPARG in the context of obesity-associated inflammation.

\section{Methodology and methods}

We used 3T3L1 mouse cells as a model of mature adipocytes. Conditioned media were prepared from 3T3L1 mature adipocytes exposed to different conditions and subsequently used for in vitro chemotaxis assays with Raw264.7 mouse macrophages cells. 10 weeks old males C57Bl6 mice (littermates) were fed a high fat diet (60\% Kcal fat, Research Diet) where rosiglitazone was directly mixed by manufacturer. Normal chow diet consisted of $13.5 \%$ kcal fat (Lab Diet).

\section{Results}

We show that treatment of adipocytes with FFAs downregulates PPARG protein and mRNA levels. Knockdown of adipocyte PPARG resulted in upregulation of MCP1 gene expression and secretion, leading to enhanced macrophage chemotaxis. Rosi inhibited these effects. In a

† Contributed equally

${ }^{1}$ Dept. of Medicine, University of California, San Diego, La Jolla, USA Full list of author information is available at the end of the article high fat feeding mouse model, we show that Rosi treatment decreases recruitment of proinflammatory macrophages to epididymal fat. This correlates with decreased chemokine and decreased chemokine receptor expression in adipocytes and macrophages, respectively.

\section{Conclusions}

In summary, we describe a novel link between FAs, PPARG, adipocytes, and adipocyte-driven recruitment of macrophages and thus provide an additional potential mechanism for the anti-inflammatory and insulinsensitizing actions of TZDs.

\section{Author details}

'Dept. of Medicine, University of California, San Diego, La Jolla, USA.

'Laboratoire CarMeN, INSERM U1060, Faculté de médecine Lyon Sud, Oullins, France.

Published: 23 November 2011

\section{References}

1. Semple RK, Chatterjee VK, O'Rahilly S: PPAR gamma and human metabolic disease. J Clin Invest 2006, 116:581-589.

2. Kersten $S$, Desvergne $B$, Wahli W: Roles of PPARs in health and disease. Nature 2000, 405:421-424.

3. Choi JH, Banks AS, Estall JL, Kajimura S, Bostrom P, Laznik D, Ruas JL, Chalmers MJ, Kamenecka TM, Bluher M, et al: Anti-diabetic drugs inhibit obesity-linked phosphorylation of PPARgamma by Cdk5. Nature 466:451-456.

4. Gregoire FM, Zhang F, Clarke HJ, Gustafson TA, Sears DD, Favelyukis $S$, Lenhard J, Rentzeperis D, Clemens LE, Mu Y, Lavan BE: MBX-102/ JNJ39659100, a novel peroxisome proliferator-activated receptor-ligand with weak transactivation activity retains antidiabetic properties in the absence of weight gain and edema. Mol Endocrinol 2009, 23:975-988.

5. Ruan H, Pownall HJ, Lodish HF: Troglitazone antagonizes tumor necrosis factor-alpha-induced reprogramming of adipocyte gene expression by inhibiting the transcriptional regulatory functions of NF-kappaB. J Biol Chem 2003, 278:28181-28192.

6. Shi H, Kokoeva MV, Inouye K, Tzameli I, Yin H, Flier JS: TLR4 links innate immunity and fatty acid-induced insulin resistance. J Clin Invest 2006, 116:3015-3025. 
7. Schenk S, Saberi M, Olefsky JM: Insulin sensitivity: modulation by nutrients and inflammation. J Clin Invest 2008, 118:2992-3002.

doi:10.1186/1479-5876-9-S2-P23

Cite this article as: Nguyen et al: Regulation of chemokine and

chemokine receptor expression by PPARG in adipocytes and

macrophages. Journal of Translational Medicine 2011 9(Suppl 2):P23.

Submit your next manuscript to BioMed Central and take full advantage of:

- Convenient online submission

- Thorough peer review

- No space constraints or color figure charges

- Immediate publication on acceptance

- Inclusion in PubMed, CAS, Scopus and Google Scholar

- Research which is freely available for redistribution

Submit your manuscript at www.biomedcentral.com/submit

() BioMed Central 